\title{
ALOKASI JOINT COST PADA SAAT SEBELUM DAN SESUDAH SPLIT OFF POINT PADA PT ISTEM
}

\author{
Hendra Galuh \\ Dosen Fakultas Ekonomi dan Bisnis Universitas Muhammadiyah Tangerang
}

Tuti Susana

Alumni Fakultas Ekonomi dan Bisnis Universitas Muhammadiyah Tangerang

\begin{abstract}
Joint Cost Allocation (joint cost) is very important for the company as one of the efforts to determine the cost of production of each product and the determination of the value of finished product inventory. The purpose of this paper is to: know the accounting methods used in treating byproducts at the time before and after the split off point, knowing the level of income from the sale of byproducts at the time before and after the split off point, knowing the internal control performed on the by products on Moment before and after split off point at PT. ISTEM.

Based on the results of the discussion and analysis of Joint Cost at the time before and after the split off point can be concluded that in making the sale of byproducts, PT ISTEM using the method without the cost of goods treated as gross income and recognized as other income. Where in its calculations, byproducts do not get a shared cost allocation from product processing before being segregated, the income from the sale of byproducts at PT ISTEM fluctuates. This is due to the sale of byproducts in each month vary.
\end{abstract}

Keywords: Joint Cost, Method Without Cost

\begin{abstract}
Abstrak
Alokasi Joint Cost (biaya bersama) sangat penting bagi perusahaan sebagai salah satu usaha untuk penentuan harga pokok produksi masing-masing produk dan penentuan nilai persediaan produk jadi. Tujuan penulisan ini adalah untuk :
\end{abstract}


mengetahui metode akuntansi yang digunakan dalam memperlakukan produk sampingan pada saat sebelum dan sesudah split off point, mengetahui tingkat pendapatan dari hasil penjualan produk sampingan pada saat sebelum dan sesudah split off point, mengetahui pengendalian intern yang dilakukan terhadap produk sampingan pada saat sebelum dan sesudah split off point pada PT. ISTEM.

Berdasarkan hasil pembahasan dan analisis Joint Cost pada saat sebelum dan sesudah split off point dapat disimpulkan bahwa dalam melakukan penjualan produk sampingan, PT ISTEM menggunakan metode tanpa harga pokok yang diperlakukan sebagai pendapatan kotor dan diakui sebagai pendapatan lain-lain. di mana dalam perhitungannya, produk sampingan tidak memperoleh alokasi biaya bersama dari pengolahan produk sebelum dipisah, Tingkat pendapatan dari hasil penjualan produk sampingan pada PT ISTEM mengalami fluktuasi. Hal ini disebabkan oleh penjualan produk sampingan pada setiap bulannya berbeda-beda.

Kata kunci : Joint Cost, Metode Tanpa Harga Pokok

\section{PENDAHULUAN}

\section{Latar Belakang Masalah}

Pada banyak perusahaan manufaktur, suatu proses produksi dihasilkan lebih dari satu jenis produk. Di perusahann industri tekstil misalnya, proses produksinya dapat menghasilkan benang, kain setengah jadi, dan kain jadi. Di perusahaan industri minyak bumi, proses penyulingan minyak mentah dapat menghasilkan bensin, minyak tanah, oli, dan lain-lain.

Bila dalam satu proses produksi dihasilkan lebih dari satu prooduksi seperti contoh di atas, maka produk tersebut disebut produk utama dan atau produk sampingan. Produk yang dihasilkan akan dinamakan produk utama atau produk sampingan akan tergantung pada nilai relatif dari produk tersebut.

Persoalan yang timbul akibat dari proses produksi yang sama dihasilkan lebih dari satu jenis produk adalah biaya yang dikeluarkan untuk semua produk tersebut, disebut biaya bersama (joint cost) yang telah dikeluarkan untuk memproduksi produk-produk yang bersangkutan, biaya bersama adalah biaya yang diolah secara 
bersama seperti, bahan baku, tenaga kerja, dan biaya overhead untuk menghasilkan beberapa produk (Bastian Bustami dan Nurlela 2013:156).

\section{LANDASAN TEORI}

Pengertian Produk Bersama

Menurut Bastian Bustami dan Nurlela (2013:155) Produk bersama adalah beberapa produk yang dihasilkan dalam suatu rangkaian atau seri produk secara bersama atau serempak dengan menggunakan bahan, tenaga kerja, dan biaya overhead secara bersama. Biaya tersebut tidak dapat ditelusuri atau dipisahkan pada setiap produk, dan setiap produk mempunyai nilai jual atau kuantitas yang relatif sama.

Dalam produk bersama dapat menghasilkan produk utama dan produk sampingan, Produk utama adalah produk yang dihasilkan dalam proses produksi secara bersama, namun mempunyai nilai atau kuantitas yang lebih besar dibandingkan dengan produk lain atau produk sampingan sedangkan produk sampingan adalah produk yang dihasilkan dalam proses produksi secara bersama, tetapi produk tersebut nilai atau kuantitasnya lebih rendah dibandingkan dengan produk lain atau produk utama.

Firdaus Ahmad Dunia dan Wasilah Abdullah (2012:158) mengungkapkan : "Produk bersama adalah dua produk atau lebih yang dihasilkan secara simultan dari suatu proses tertentu, di mana masing-masing produk mempunyai nilai penjualan yang relatif besar atau berarti."

\section{Karakteristik Produk Bersama}

Menurut Mulyadi (2010:335) produk bersama memiliki karakteristik

1. Produk bersama merupakan tujuan utama kegiatan produksi.

2. Harga jual produk bersama relatif tinggi bila dibandingkan dengan produk sampingan yang dihasilkan pada saat yang sama.

\section{Aliran Produk dan Aliran Biaya}




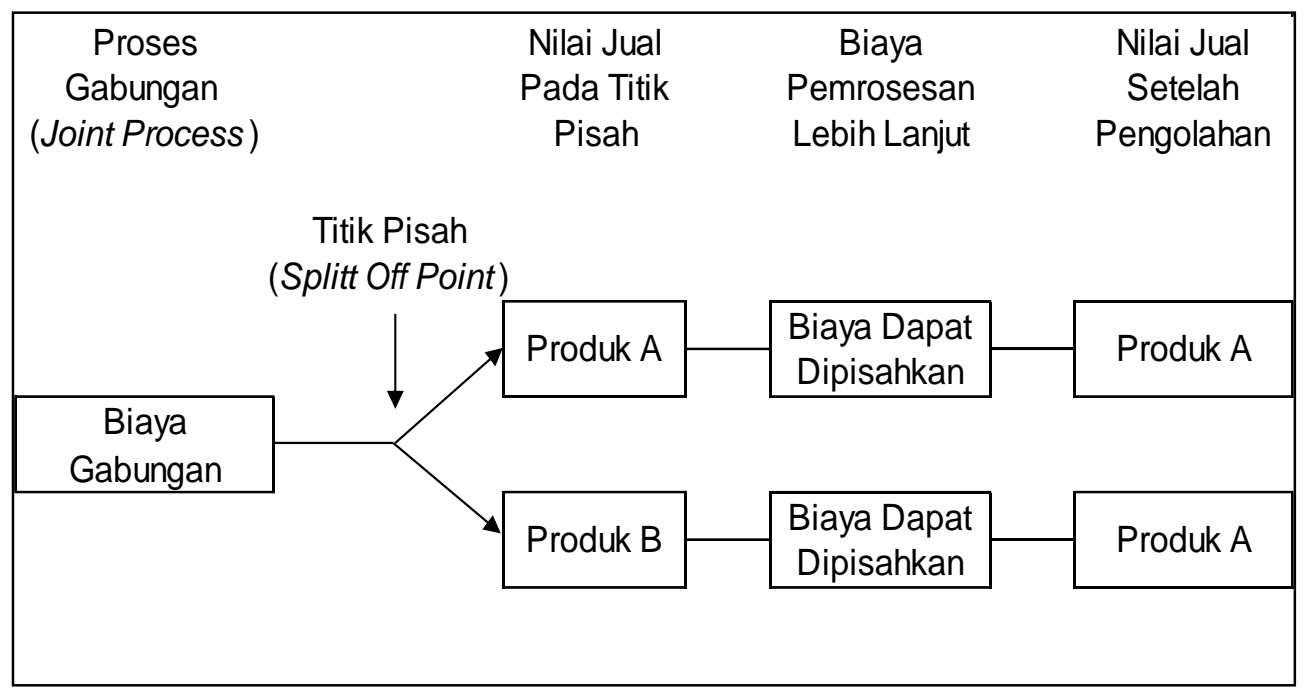

\section{Metode Alokasi Biaya Bersama}

Bastian Bustami dan Nurlela (2013:157) mengungkapkan :“Alokasi biaya adalah pembebanan biaya secara proporsional dari biaya tidak langsung atau biaya bersama ke objek biaya."

William K. Carter (2010:269) mengungkapkan :"Secara umum alokasi biaya tersebut ditujukan untuk berbagai alasan sebagai berikut :

1. Menghitung harga pokok dan menentukan persediaan untuk tujuan pelaporan keuangan internal.

2. Menghitung harga pokok dan menentukan persediaan untuk tujuan pelaporan keuangan eksternal.

3. Menilai persediaan untuk tujuan asuransi.

4. Menentukan nilai persediaan jika terjadi kerusakan terhadap nilai barang yang rusak.

5. Biaya bahan yang hancur.

6. Menentukan biaya departemen atau devisi untuk tujuan pengukuran kinerja eksekutif. 
7. Pengaturan tarif karena adanya sebagian produk atau jasa yang diproduksi dikenakan peraturan harga."

\section{Metode Alokasi Biaya Bersama}

1. Metode harga pasar / metode nilai jual hipotesis

Bastian Bustami dan Nurlela (2013:158) mengungkapkan Metode harga pasar atau nilai jual merupakan pembebanan biaya bersama atas dasar nilai jual masing-masing produk.

William K. Carter (2010:275) mengungkapkan Metode harga jual dapat dibedakan menjadi :

a. Harga jual diketahui pada saat titik pisah

Rumus :

Pembebanan biaya bersama $=$

Jumlah nilai jual masing-masing produk

X Biaya bersama

Jumlah nilai jual keseluruhan produk

b. Harga jual tidak diketahui pada titik pisah

Apabila suatu produk tidak bisa dijual pada titik pisah, maka harga tidak dapat diketahui pada saat titik pisah. Produk tersebut memerlukan proses tambahan sehingga harga jual dapat diketahui setelah proses. Dasar yang digunakan dalam mengalokasikan biaya bersama adalah harga pasar hipotesis.

Harga pasar hipotesis adalah nilai jual suatu produk setelah diproses lebih lanjut dikurangi dengan biaya yang dikeluarkan untuk memproses lebih lanjut.

(Harga Pasar Hipotesis = Nilai Jual - Biaya Proses Lanjut $). ”$ 
Rumus :

Pembebanan Biaya Bersama $=$

Jumlah nilai jual hipotesis masing-

masing produk setelah titik pisah

XBiaya Bersama

Jumlah nilai jual hipotesis seluruh

produk setelah titik pisah

2. Metode unit fisik

Armanto Witjaksono (2013:107) mengungkapkan :Metode unit fisik adalah suatu metode dalam pembebanan biaya bersama kepada produk didasarkan atas unit secara fisik atau output dari suatu produk.

Penggunaan metode ini dapat dinyatakan dalam rumus sebagai berikut :

Pembebanan biaya bersama $=$

Jumlah unit masing-masing produk

X Biaya bersama

Jumlah unit keseluruhan produk

3. Metode rata-rata sederhana

William K. Carter (2010:279) mengungkapkan Metode rata-rata sederhana atau rata-rata per unit adalah suatu metode dalam mengalokasikan biaya bersama bahwa seluruh produk yang dihasilkan dari proses produksi bersama harus dibebani suatu nilai secara proporsional dari seluruh biaya bersama atau dari besarnya unit yang diproduksi."

Metode ini dapat dinyatakan dalam rumus sebagai berikut :

Pembebanan Biaya Bersama $=$

Biaya per unit X Jumlah unit masing-masing produk

Biaya per unit $=$ 
Jumlah biaya bersama / Jumlah unit keseluruhan produk

4. Metode rata-rata tertimbang

Mulyadi (2010:340) mengungkapkan Metode rata-rata tertimbang adalah suatu metode dalam mengalokasikan biaya bersama berdasarkan kepada unit produksi dan dikalikan dengan faktor penimbang, kemudian diperoleh jumlah penimbang rata-rata setiap produk dibagi dengan jumlah penimbang rata-rata seluruh produk.

Metode ini dapat dinyatakan dalam rumus sebagai berikut :

Pembebanan biaya bersama $=$

Jumlah penimbang rata-rata setiap produk

X Biaya bersama

Jumlah penimbang rata-rata seluruh produk

\section{Produk Sampingan}

R.A. Supriyono (2010:238) mengungkapkan :"Produk sampingan adalah produk yang dihasilkan dalam proses produksi secara bersama, tetapi produk tersebut nilai atau kuantitasnya lebih rendah dibandingkan dengan produk utama."

Adapun pengelompokan produk sampingan menurut Armanto Witjaksono (2013:107)di dalam bukunya mengungkapkan : "Produk sampingan dapat dikelompokkan sebagai berikut :

1. Produk sampingan yang siap dijual setelah dipisah dari produk utama.

2. Produk sampingan yang memerlukan proses lebih lanjut.

3. Produk sampingan yang siap dijual setelah titik pisah dari produk utama, tetapi dapat diproses lebih lanjut agar dapat dijual dengan harga yang lebih tinggi." 
Selain itu metode yang dapat digunakan dalam perhitungan harga pokok produk sampingan adalah :

\section{Metode Tanpa Harga Pokok}

Bastian Bustami dan Nurlela (2013:166) mengungkapkan : "Metode tanpa harga pokok adalah suatu metode dalam perhitungan produk sampingan tidak memperoleh alokasi biaya bersama dari pengolahan produk sebelum dipisah. metode tanpa harga pokok ini dapat dibedakan sebagai berikut :

a. Pengakuan Atas Pendapatan Kotor

Dalam pengakuan atas pendapatan kotor produk sampingan dapat diperlakukan sebagai penambah penjualan atau pendapatan produk utama, sebagai pengurang harga pokok penjualan atau bisa juga diperlakukan sebagai pengurang biaya produksi.

b. Pengakuan Atas Pendapatan Bersih

Kautsar Riza Salman (2013:141) mengungkapkan Dasar yang digunakan untuk mengalokasikan biaya produksi bersama ke produk utama adalah jumlah pendapatan yang diperoleh dari hasil penjualan produk sampingan setelah dikurangi dengan seluruh biaya yang terjadi setelah titik pisah.”

2. Metode Dengan Harga Pokok

Bastian Bustami dan Nurlela (2013:173) mengungkapkan : "Metode dengan harga pokok merupakan suatu metode di mana produk sampingan memperoleh alokasi biaya bersama sebelum dipisah dari produk utama." Metode dengan harga pokok terdiri dari Produk Sampingan Sebagai Harga Pokok Pengganti dan Produk Sampingan Sebagai Harga Pokok Pembatalan Biaya (Reversal Costs).

\section{Metodologi Penulisan}

\section{Pendekatan Penelitian}

Jenis penelitian yang digunakan adalah studi lapangan yaitu penelitian yang dilakukan secara langsung pada perusahaan yang bersangkutan untuk 
memperoleh data sekunder dan informasi yang dibutuhkan. Teknik pengumpulan data dilakukan dengan observasi yaitu mengadakan kegiatan pengamatan langsung terhadap objek penelitian untuk lebih memahami kondisi perusahaan. Dan juga menggunakan studi pustaka yaitu mencari dan mengumpulkan bahan yang berhubungan dengan masalah yang diteliti dengan cara membaca, mempelajari, dan mendalami literatur-literatur maupun referensi yang berhubungan dengan masalah yang dibahas dalam tugas akhir ini.

\section{Objek dan Subjek Penelitian}

objek dalam penelitian ini adalah analisis joint cost dengan metode tanpa harga pokok

Subjek dalam penelitian ini adalah PT. Indonesia Synthetic Textile Mills (PT ISTEM) yang merupakan perusahaan industri yang bergerak di bidang tekstil. Dan yang menjadi

\section{Jenis Data}

Metode pengumpulan data yang digunakan adalah dengan menggunakan metode penelitian kepustakaan yaitu dengan mengacu kepada buku-buku yang berkaitan dengan penelitian serta sumber data yang berasal dari dokumen (data sekunder).

\section{Teknik Pengumpulan Data}

Teknik pengumpulan data yang digunakan dalam penelitian adalah sebagai berikut : Penelitian Lapangan (Field Research) merupakan teknik pengumpulan data yang dilakukan dengan cara terjun langsung pada objek penelitian untuk mendapatkan data yang diperlukan yang meliputi wawancara dan observasi. Penelitian Kepustakaan (Library Research) peneliti memperoleh dari literature, buku-buku referensi yang berhubungan dengan dengan masalah untuk memperoleh data sekunder sebagai landasan teori.

\section{Hasil Penelitian dan Pembahasan}

Berikut adalah data mengenai joint cost pada PT ISTEM : 


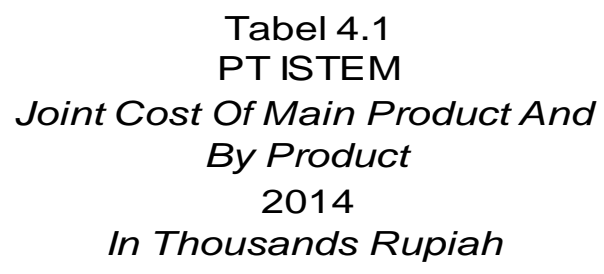

\begin{tabular}{|l|lr|}
\hline \multicolumn{1}{|c|}{ Months } & \multicolumn{2}{|c|}{ Joint Cost } \\
\hline January & $R p$ & 1.118 .559 \\
February & $R p$ & 991.233 \\
March & $R p$ & 945.850 \\
April & $R p$ & 1.000 .393 \\
May & $R p$ & 976.989 \\
June & $R p$ & 996.254 \\
July & $R p$ & 1.010 .947 \\
August & $R p$ & 901.000 \\
September & $R p$ & 983.736 \\
October & $R p$ & 1.000 .291 \\
November & $R p$ & 905.437 \\
Desember & $R p$ & 989.674 \\
\hline
\end{tabular}

Sumber : PT ISTEM

Analisis Joint Cost menggunakan metode tanpa harga pokok

1. Penjualan produk sampingan selama tahun 2014 pada PT ISTEM

Tabel 4.2

Summary for waste sold to PT. Toray International Indonesia for the month of January 2014

Invoice No: 0019

\begin{tabular}{|c|c|c|c|c|}
\hline NO & DESCRIPTIONS & \begin{tabular}{|c} 
QUANTITY \\
KGS
\end{tabular} & $\begin{array}{c}\text { UNIT PRICE } \\
\text { RP }\end{array}$ & $\begin{array}{c}\text { AMOUNT } \\
\text { RP }\end{array}$ \\
\hline 1 & Yarn Waste & $6.092,00$ & $1.727,27$ & 10.522 .529 \\
\hline 2 & Flat Waste & 237,00 & $2.863,64$ & 678.683 \\
\hline 3 & Sayoment Waste & 528,00 & $3.613,64$ & 1.908 .002 \\
\hline 4 & Cleaner Waste & 280,00 & $1.454,55$ & 407.274 \\
\hline 5 & Staple Waste & 293,00 & $1.818,18$ & 532.727 \\
\hline 6 & Waste Ex Spinning No.3 & $1.383,00$ & $1.818,18$ & 2.514 .543 \\
\hline \multirow[t]{4}{*}{7} & Short Fiber Waste & 115,00 & $1.727,27$ & 198.636 \\
\hline & TOTAL & 8.928 & & 16.762 .393 \\
\hline & PPN 10\% & & & 1.676 .239 \\
\hline & TOTAL AMOUNT & & & 18.438 .632 \\
\hline
\end{tabular}

Sumber : PT ISTEM

Jurnalnya :

Cash / Account Receivable

Rp 16.762.393

VAT Out

Rp 1.676 .239

By Product Income

Rp 18.438.632 
2. Alokasi biaya bersama (joint cost) produk utama dan produk sampingan selama tahun 2014 pada PT ISTEM

$$
\begin{aligned}
& \text { Tabel } 4.13 \\
& \text { PT ISTEM }
\end{aligned}
$$

Unit Of Joint Product And By Product 2014

\begin{tabular}{|l|r|r|r|}
\hline \multicolumn{1}{|c|}{ Months } & $\begin{array}{c}\text { Joint Prodct } \\
\text { Kgs }\end{array}$ & $\begin{array}{c}\text { By Product } \\
\text { Kgs }\end{array}$ & $\begin{array}{c}\text { \% Of } \\
\text { By }\end{array}$ \\
\hline January & $780.178,58$ & $10.315,32$ & 1,32 \\
February & $700.000,00$ & $9.140,27$ & 1,31 \\
March & $744.468,52$ & $9.581,19$ & 1,29 \\
April & $846.807,09$ & $10.943,63$ & 1,29 \\
May & $766.816,54$ & $10.046,36$ & 1,31 \\
June & $794.729,62$ & $10.531,37$ & 1,33 \\
July & $678.780,00$ & $9.305,62$ & 1,37 \\
August & $737.281,64$ & $9.865,59$ & 1,34 \\
September & $806.687,03$ & $10.758,45$ & 1,33 \\
October & $832.895,00$ & $11.664,54$ & 1,40 \\
November & $858.498,31$ & $11.560,92$ & 1,35 \\
Desember & $860.475,83$ & $11.717,45$ & 1,36 \\
\hline Sumber : PT ISTEM
\end{tabular}

Tingkat Pendapatan Produk Sampingan Pada PT ISTEM.

Berikut adalah tingkat pendapatan dari hasil penjualan produk sampingan pada PT ISTEM.

Tabel 4.26

Sales Of By Product

PT ISTEM

2014

\begin{tabular}{|l|r|lr|}
\hline \multicolumn{1}{|c|}{ Months } & \multicolumn{1}{c|}{$\begin{array}{c}\text { Unit Sales } \\
\text { Kgs }\end{array}$} & \multicolumn{2}{|c|}{ Total Amount } \\
\hline January & 8.928 & $\mathrm{Rp}$ & 18.438 .632 \\
February & 10.238 & $\mathrm{Rp}$ & 20.745 .103 \\
March & 9.622 & $\mathrm{Rp}$ & 19.334 .779 \\
April & 14.200 & $\mathrm{Rp}$ & 29.188 .671 \\
May & 9.576 & $\mathrm{Rp}$ & 19.769 .181 \\
June & 9.850 & $\mathrm{Rp}$ & 20.173 .154 \\
July & - & $\mathrm{Rp}$ & \\
August & 22.340 & $\mathrm{Rp}$ & 46.893 .115 \\
September & 3.432 & $\mathrm{Rp}$ & 8.153 .909 \\
October & 27.741 & $\mathrm{Rp}$ & 60.312 .734 \\
November & 12.158 & $\mathrm{Rp}$ & 26.891 .186 \\
Desember & 10.642 & $\mathrm{Rp}$ & 23.898 .882 \\
\hline
\end{tabular}

Sumber : PT ISTEM 
Dari tabel informasi mengenai data penjualan di atas, dapat digambarkan grafik sebagai berikut :

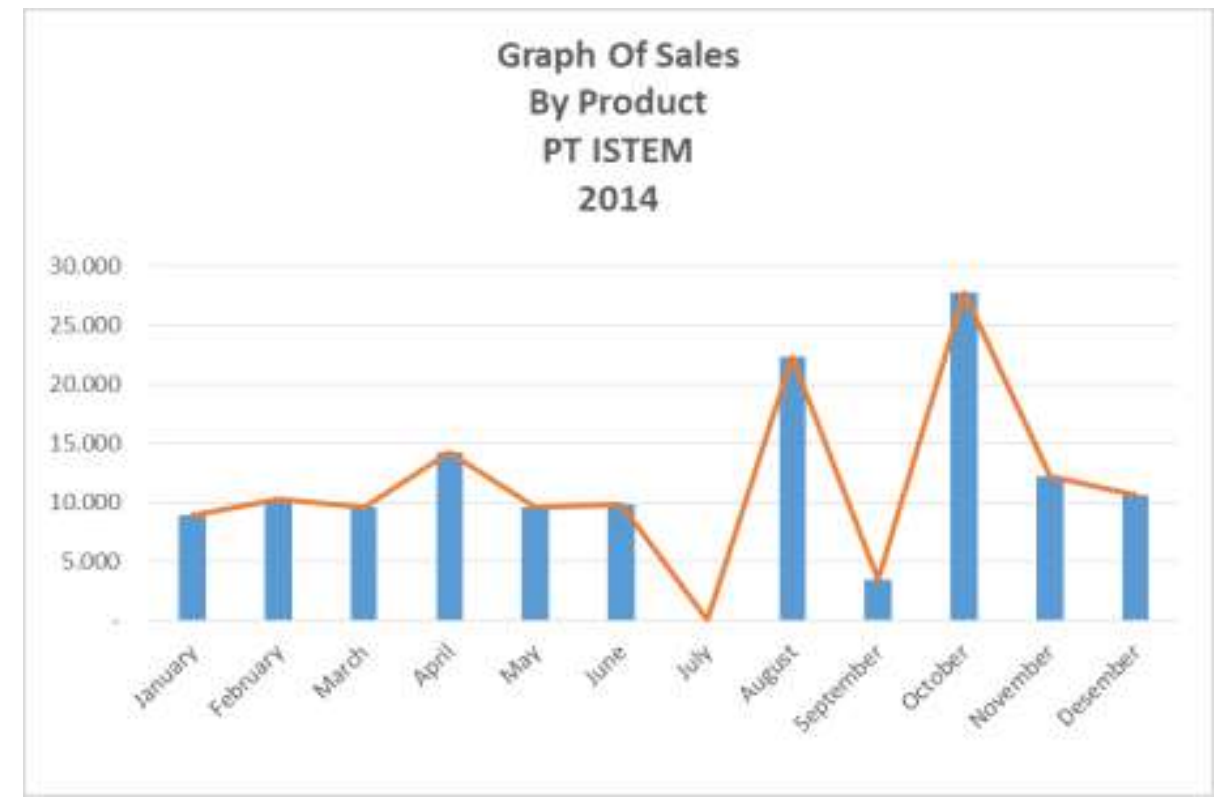

Sumber : PT ISTEM

Dari grafik di atas, dapat diambil kesimpulan sebagai berikut :

1. Penghasilan atas penjualan produk sampingan pada PT ISTEM di tahun 2014 dari bulan ke bulan mengalami fluktuasi.

2. Tingkat penjualan tertinggi terjadi pada bulan Oktober 2014 dengan penjualan sebanyak $27.741 \mathrm{~kg}$.

3. Tingkat penjualan terendah terjadi pada bulan Juli 2014 dan dapat dikatakan bahwa pada bulan ini PT ISTEM tidak melakukan penjualan produk sampingan.

4. Rata-Rata penjualan produk sampingan pada PT ISTEM di tahun 2014 adalah sebesar $11.561 \mathrm{~kg}$.

Analisa yang diperoleh berdasarkan grafik di atas adalah sebagai berikut :

1. Pada bulan Juli 2014 terjadi penurunan penjualan produk sampingan yang sangat drastis dari bulan sebelumnya. Hal ini dikarenakan pada bulan Juli 2014, PT ISTEM menghasilkan 9.305,62 Kg produk sampingan. Akan tetapi pada bulan tersebut tidak adanya penjualan. 
2. Pada bulan September 2014 terjadi penurunan yang sangat rendah dibandingkan dengan penjualan bulan sebelumnya. Hal ini dikarenakan pada bulan September 2014, PT ISTEM menghasilkan 10.758,45 Kg produk sampingan, akan tetapi yang terjual hanya $3.432 \mathrm{Kg}$.

3. Pada Bulan September terjadi penjualan produk sampingan yang sangat tinggi dibandingkan dengan bulan September dengan penjualan sebesar $27.741 \mathrm{Kg}$ sedangkan pada bulan tersebut, PT ISTEM hanya menghasilkan produk sampingan sebesar 11.664,54. Hal ini dikarenakan adanya penambahan kuantitas yang berasal dari persediaan akhir dari bulan-bulan sebelumnya.

\section{Kesimpulan}

Dari seluruh pembahasan yang telah penulis buat tentang alokasi joint cost produk sampingan pada PT ISTEM, dapat disimpulkan bahwa:

1. Dalam melakukan penjualan produk sampingan, PT ISTEM menggunakan metode tanpa harga pokok yang diperlakukan sebagai pendapatan kotor dan diakui sebagai pendapatan lain-lain. PT ISTEM menerapkan metode tanpa harga pokok di mana dalam perhitungannya, produk sampingan tidak memperoleh alokasi biaya bersama dari pengolahan produk sebelum dipisah. Kemudian dari metode tanpa harga pokok ini diperlakukan sebagai pendapatan kotor di mana produk sampingan dapat langsung dijual pada saat titik pisah tanpa harus melalui proses pengolahan lebih lanjut. Dari pendapatan kotor ini, PT ISTEM mengakui pendapatan penjualan produk sampingan ini sebagai pendapatan lain-lain di mana pendapatan ini berasal dari sumber di luar kegiatan utama perusahaan.

2. Tingkat pendapatan dari hasil penjualan produk sampingan pada PT ISTEM mengalami fluktuasi. Hal ini disebabkan oleh penjualan produk sampingan pada setiap bulannya berbeda-beda sehingga PT ISTEM mendapatkan penghasilan dari kegiatan ini pun beragam. Pada tahun 2014, PT ISTEM mengalami fluktuasi atas penjualan produk sampingan di mana penghasilan terbesar terjadi pada bulan Juni dengan pendapatan sebesar Rp 
60.312.734 dan pada bulan Juli, PT ISTEM tidak mengalami penjualan produk sampingan sehingga tidak ada penghasilan dalam kegiatan ini.

\section{Daftar Pustaka}

Bustami, Bastian, dan Nurlela, Akuntansi Biaya, Jakarta, Mitra Wacana Media, 2013.

Carter, William K, Cost Accounting, Jakarta, Salemba Empat, 2010.

Dewi, Sofia Prima, dan Septian Bayu Kristanto, Akuntansi Biaya, Jakarta, In Media, 2015.

Dunia, Firdaus Ahmad, dan Wasilah Abdullah, Akuntansi Biaya, Jakarta, Salemba Empat, 2012.

Ikatan Akuntan Indonesia, Standar Akuntansi Keuangan, Jakarta, Salemba Empat, 2010.

Mulyadi, Akuntansi Biaya, Yogyakarta, STIM YKPN, 2010.

Salman, Kautsar Riza, Akuntansi Biaya, Jakarta, Akademia Permata, 2013.

Supriyono, RA, Akuntansi Biaya, Yogyakarta, BPFE, 2010.

Witjaksono, Armanto, Akuntansi Biaya, Jakarta, Graha Ilmu, 2013. 